\title{
Pengaruh Coronavirus Disease 2019 Terhadap Jenis Kelamin Dan Manifestasi Neurologi : Systematic Review
}

\author{
Ali Fendi ${ }^{1}$, Rohman Azzam ${ }^{1}$, Mustikasari ${ }^{2}$ \\ 1. Program Studi Magister Keperawatan, Universitas Muhammadiyah Jakarta \\ 2. Fakultas IImu Keperawatan, Universitas Indonesia \\ E-mail : gunung41@yahoo.co.id
}

\begin{abstract}
Abstrak
Latar Belakang: Coronavirus Disease 2019 (Covid-19) saat ini menjadi permasalahan dunia yang serius dengan jumlah kasusnya yang selalu mengalami peningkatan setiap harinya. Tujuan: Untuk mengetahui pengaruh infeksi coronavirus disease 2019 terhadap jenis kelamin dan manifestasi neurologis. Metode: systematic review dengan mengumpulkan penelitian dari tahun 2019-2020 menggunakan database google scholar dan pubmed dengan kata kunci Coronavirus disease 2019 dan manifestasi neurologis sehingga diperoleh Hasil: 576 artikel/jurnal. Dilakukan seleksi sesuai kriteria inklusi maka diperoleh 22 artikel/jurnal. Laki-laki lebih banyak terinfeksi Covid-19 daripada perempuan. Manifestasi neurologis yang ditemukan adalah gangguan sistem saraf pusat (pusing, sakit kepala, gangguan kesadaran, penyakit serebrovaskular akut, kejang dan ataksia), gangguan sistem saraf tepi (Gangguan penciuman, perasa dan gangguan penglihatan) dan cedera otot rangka (Syndrome Guillane Barre (SGB)). Kesimpulan: infeksi coronavirus disease 2019 lebih banyak diderita laki-laki daripada perempuan dengan 3 manifestasi neurologis : gangguan sistem saraf pusat, gangguan sistem saraf tepi dan gangguan cedera otot. Oleh karena itu untuk memutus rantai infeksi agar selalu menjalankan protokol kesehatan seperti memakai masker, mencuci tangan dan menjaga jarak.
\end{abstract}

Kata Kunci : Coronavirus disease 2019 dan manifestasi Neurologis.

\begin{abstract}
Background: Coronavirus Disease 2019 (Covid-19) is currently a serious world problem with the number of cases increasing every day. Objective: To determine the effect of coronavirus disease 2019 infection on gender and neurological manifestations. Methods: systematic review by collecting research from 2019-2020 using the google scholar and pubmed databases with the keywords Coronavirus disease 2019 and neurological manifestations in order to obtain Results: 576 articles/journals. Selection was made according to the inclusion criteria, so 22 articles/journals were obtained. More men are infected with Covid-19 than women. Neurological manifestations found were central nervous system disorders (dizziness, headache, impaired consciousness, acute cerebrovascular disease, seizures and ataxia), peripheral nervous system disorders (olfactory, taste and visual disturbances) and skeletal muscle injuries (Guillane Barre Syndrome (GBS). )). Conclusion: infection with coronavirus disease 2019 affects more men than women with 3 neurological manifestations: central nervous system disorders, peripheral nervous system disorders and muscle injury disorders. Therefore, to break the chain of infection, always follow health protocols such as wearing masks, washing hands and maintaining distance.
\end{abstract}

Keywords : Coronavirus disease 2019 and Neurological manifestations. 


\section{PENDAHULUAN}

Coronavirus Disease 2019 (Covid-19) telah menjadi masalah kesehatan Dunia, yang terjadi pertama kali pada tanggal 31 Desember 2019 di kota Wuhan, Provinsi Hubei, China (WHO,2020). Covid-19 adalah penyakit menular yang disebabkan oleh Coronavirus Severe Acute Respiratory Syndrome (SARS-COV-2). Badan Kesehatan Dunia menetapkan Covid-19 sebagai Kedaruratan Kesehatan Masyarakat yang Meresahkan Dunia (KKMMD) yang artinya peristiwa luarbiasa yang menjadi resiko kesehatan publik bagi negara lain melalui penyebaran penyakit internasional, serta memerlukan respon internasional yang terkoordinasi. Oleh karena itu, badan kesehatan dunia (WHO) pada tanggal 11 Maret 2020 menetapkan Covid-19 sebagai Pandemi.

$$
\text { Infeksi Covid-19 menyebabkan }
$$
penyakit pernapasan mulai dari gejala ringan, sedang sampai berat. Namun ada beberapa penelitian yang melaporkan bahwa banyak pasien dengan Covid-19 tidak menunjukkan gejala atau hanya memiliki gejala ringan, tetapi mereka dapat menularkan virus ke orang lain, seperti penelitian (Li et al., 2020) melaporkan dari satu keluarga dengan 5 anggota yang dirawat, tanpa menunjukkan gejala apapun. Juru bicara BNPB melaporkan bahwa kasus yang dapatkan akhir-akhir ini sangat signifikan terutama pada kelompok konfirmasi Covid-19 tanpa gejala atau Asimpotmaitk (Yurianto, 2020).

Penelitian yang dilakukan oleh (Guan et al., 2020) melaporkan bahwa dari 1099 pasien terinfeksi Covid-19, Gejala yang paling umum ditemukan berkaitan dengan sistem pernafasan seperti demam, batuk dan sesak nafas. Penelitian terkini menemukan adanya peran reseptor Angiotesin Converting Enzyme-2 (ACE2) terhadap infeksi SARS-CoV2 (Covid-19). (Y. Zhao et al., 2020) menyatakan bahwa ekspresi reseptor virus ACE2 terkonsentrasi dalam sel alveolar tipe II (AT2). AT2 berfungsi untuk mengatur reproduksi dan transmisi virus. Artikel review dari (Ikawaty, 2020) menyatakan bahwa ACE2 banyak ditemukan pada organ paruparu, saluran pencernaan, jantung dan pembuluh darah, ginjal, otot polos, kulit, mulut dan hidung, hati, plasenta dan otak. ACE2 pada organ otak memiliki intensitas yang tinggi terutama di neuron, sel ganglia, dan endotel pembuluh darah serebral.

Review yang dilakukan oleh (Pinzon et al.,2020) pada bulan April 2020 menyatakan bahwa cedera otot merupakan gejala neurologis yang paling umum ditemukan. Namun akhir-akhir ini banyak penelitian tentang gangguan penciuman dan perasa merupakan gejala umum pada pasien yang terinfeksi Coronavirus disease 2019 seperti penelitian experiment yang dilakukan oleh (Moien et al., 2020) pada pasien rawat inap di pennsylvania-Amerika Serikat yang 
menyatakan bahwa 59 dari 60 pasien mengalami gangguan penciuman sehingga disimpulkan bahwa Gangguan penciuman merupakan penanda terinfeksi Covid-19. Review yang dilakukan oleh (Mullol et al., 2020) tentang gangguan penciuman dan perasa pada wabah Covid-19 di banyak negera, ia menyimpulkan bahwa gangguan penciuman dan perasa pada pasien Covid-19 berkisar antara 5-98\% tergantung metodologi penelitian dan negaranya.

\section{METODE}

Penelitian ini merupakan penelitian dengan menggunakan metode studi kepustakaan atau systematic review. Systematic review merupakan metode penelitian untuk merangkum secara menyeluruh beberapa penelitian kemudian dianalisis. Penelitian ini dilakukan bukan untuk mencari intervensi Covid-19 pada jenis kelamin dan menifestasi neurologis melainkan untuk mencari keterlibatan Covid-19 terhadap jenis kelamin dan manifestasi neurologis. Pancarian literature dilakukan pada bulan Januari - Juli 2020. Data yang digunakan dalam penelitian ini adalah data sekunder yang diperoleh dari hasil penelitian yang telah dilakukan oleh peneliti-peneliti terdahulu. Sumber data sekunder yang didapat berupa artikel/jurnal yang didapat dari 2 database ilmiah yang tersedia yaitu google scholar dan pubmed.

\begin{tabular}{|l|l|}
\hline \multicolumn{1}{|c|}{ Kriteria } & \multicolumn{1}{|c|}{ Inklusi } \\
\hline $\begin{array}{l}\text { Jangka } \\
\text { waktu }\end{array}$ & $\begin{array}{l}\text { Rentang waktu penerbitan } \\
\text { artikel / jurnal adalah tahun } \\
2019-2020 .\end{array}$ \\
\hline Bahasa & $\begin{array}{l}\text { Bahasa yang digunakan adalah } \\
\text { Inggris. }\end{array}$ \\
\hline Subyek & $\begin{array}{l}\text { Pasien yang terinfeksi } \\
\text { Coronavirus Disease-2019. }\end{array}$ \\
\hline $\begin{array}{l}\text { Jenis artikel } \\
\text { / Jurnal }\end{array}$ & $\begin{array}{l}\text { Cross Sectional, Systematic } \\
\text { Review, Retrospektif, } \\
\text { Prospektif, Studi Kasus. }\end{array}$ \\
\hline $\begin{array}{l}\text { Tema isi } \\
\text { artikel } \\
\text { jurnal }\end{array}$ & $\begin{array}{l}\text { Manifestasi klinis Neurologis, } \\
\text { Coronavirus Disease-2019 }\end{array}$ \\
\hline
\end{tabular}

Kriteria Eksklusi dari systematic literature ini adalah : apabila ditemukan artikel/jurnal yang tidak sesuai dengan kriteria inklusi maka artikel/jurnal tersebut akan dikeluarkan.

\section{HASIL}

Pencarian artikel/jurnal dimulai dengan mencari di dua database yaitu google scholar dan Pubmed dengan memasukkan kata coronaviruse disease 2019 dan atau neurologic manifestations dengan membuat saringan tahun, abstrak, dan memilih jenis artikel, dari pencarian tersebut ditemukan 220 artikel pada database Pubmed dan 356 artikel pada database google scholar. Artikel yang telah ditemukan kemudian dilakukan skrining sebanyak 498 artikel dikarenakan dalam artikel tersebut tidak ditemukan manifestasi neurologi atau terdapat manifestasi selain neurologi, terdapat artikel yang sama (duplikasi) antara artikel yang terdapat di database Pubmed dan database google scholar, Bahasa yang digunakan tidak 
dalam Bahasa inggris (terdapat Bahasa China, Italia dan Jerman) sehingga artikel tersebut di keluarkan (dieksklusi) dan tersisa 78 artikel. Kemudian 78 artikel di skrining kembali untuk mencari artikel yang lengkap, ditemukan 22 artikel/jurnal dengan teks yang lengkap sehingga dijadikan sebagai bahan review.

Analisis review

A. Jenis Kelamin

Penderita Coronavirus disease 2019 (Covid-19) diseluruh dunia sudah mencapai 14 juta jiwa. Di Indonesia pada tanggal 20 Juli 2020 sudah mencapai 86.521 jiwa, dimana jenis kelamin laki-laki mendominasi kejadian infeksi Covid-19. Dari data gugus tugas percepatan penanganan Covid-19 BNPB, jumlah lakilaki terinfeksi Covid-19 sebesar 45.164 $(52,2 \%)$ orang sedangkan jumlah perempuan terinfeksi Covid-19 sebesar $41.357(47,8 \%)$ orang. Chen et al (2020) yang meneliti tentang "Clinical characteristics of 113 deceased patients with coronavirus disease 2019: retrospective study" yang melibatkan 274 terdiri dari 172 (62\%) pasien adalah lakilaki sedangkan 103 (38\%) pasien adalah perempuan. Giacomelli et al (2020) yang meneliti tentang "Self-reported olfactory and taste disorders in SARS-CoV-2 patients: a cross-sectional study. Clinical Infectious Diseases: An Official Publication of the Infectious Diseases Society of America", dari 59 pasien yang dijadikan responden, $40(67,8 \%)$ pasien jenis kelamin laki-laki sedangkan 19 $(32,2 \%)$ pasien berjenis kelamin perempuan. Qiu et al (2020) yang meneliti tentang "Olfactory and Gustatory Dysfunction as an Early Identifier of COVID-19 in Adults and Children: An International Multicenter Study" yang melibatkan 394 pasien terdiri dari 161 orang mengalami gangguan penciuman / perasa, 92 (57\%) pasien adalah laki-laki dan 69 (43\%) pasien adalah perempuan.

\section{B. Manifestasi Neurologis}

a. Sistem Saraf Pusat

Beberapa penelitian telah melaporkan adanya bukti bahwa SARSCoV-2 tidak hanya menyerang sistem pernafasan tetapi dapat juga menyerang organ yang lain termasuk sistem neurologis. Mao et al (2020) melaporkan bahwa dari 214 pasien yang menjadi responden dengan 87 laki-laki yang terinfeksi Covid-19, 126 pasien mengalami infeksi ringan dan 88 pasien mengalami infeksi yang parah. Manifestasi neurologis pada sistem saraf pusat seperti pusing, sakit kepala, gangguan kesadaran, penyakit serebrovaskular akut, ataksia, dan kejang. Penelitian lain dari Chen et al (2020) melaporkan bahwa manifestasi neurologis dari 274 pasien yang ditemukan adalah myalgia 60 pasien, 
mual dan muntah 30 pasien, sakit kepala 31 pasien dan pusing 21 pasien, sedangkan penyakit serebrovaskuler sebagai komorbiditas lebih tinggi terjadi pada 4 pasien yang meninggal daripada pasien yang sembuh.

b. Sistem Saraf Tepi

\section{Gangguan Penciuman dan Perasa}

Sejumlah pasien yang terinfeksi Covid-19 dilaporkan mengalami gangguan pada indera penciuman (Anosmia) dan indera perasa (Ageusia). Gangguan penciuman dan gangguan perasa diketahui berhubungan dengan berbagai infeksi virus. SARS-CoV telah menunjukkan dalam model tikus, penetrasi transneural melalui olfactory bulb. Selain itu, receptor Angiotensin-Converting Enzyme 2 (ACE2) yang digunakan oleh SARSCoV-2 untuk mengikat dan menembus ke dalam sel epitel mukosa rongga mulut, temuan ini yang mendasari adanya gangguan penciuman dan gangguan perasa pada penderita Covid-19.

Penelitian dari Altin et al (2020) menyatakan bahwa gangguan penciuman dan gangguan perasa terkait erat dengan infeksi Covid-19. Penelitian lain yang dilakukan oleh Giacomelli et al (2020) dengan metode cross- sectional yang melibatkan 59 responden, 20 (33,9\%) responden melaporkan adanya gangguan rasa dan atau penciuman. Gangguan penciuman dan gangguan perasa dikaitkan dengan perjalanan klinis yang ringan-sedang pada penderita Covid-19.

Penelitian yang dilakukan oleh Lechien et al (2020) sebanyak 417 pasien Covid-19 dengan gejala ringan-sedang dilaporkan 85,6\% pasien mengalami gangguan penciuman sedangkan $88,0 \%$ melaporkan gangguan perasa, sehingga adanya hubungan yang signifikan antara gangguan penciuman dan gangguan perasa. Gangguan penciuman muncul sebelum gejala lain pada $11,8 \%$ kasus dan $18,2 \%$ pasien tanpa sumbatan hidung, sehingga disimpulkan bahwa gangguan penciuman dan gangguan perasa merupakan gejala yang lazim terjadi pada pasien terinfeksi Covid-19 yang tidak memiliki gejala sumbatan hidung. Penelitian yang dilakukan oleh Qiu et al (2020) menyimpulkan gangguan penciuman kemungkinan merupakan gejala awal dari infeksi Covid-19. 
Penelitian yang dilakukan oleh Chary et al (2020) yang melibatkan 115 pasien, 81 (70\%) melaporkan gangguan penciuman tanpa sumbatan hidung. Gangguan ini lebih sering dilaporkan pada wanita muda dengan gejala ringan. Sonja A. Rasmussen, MD, MS (2020) menyatakan bahwa gangguan penciuman merupakan predictor kuat infeksi Covid-19. Review yang dilakukan oleh Mehraeen et al (2020) melaporkan bahwa dari 24 artikel penelitian terkini, 95,8 \% penelitian mengkonfirmasi gejala gangguan penciuman (anosmia) pada pasien dengan infeksi SARSCov-2.

\section{Gangguan Penglihatan}

Coronavirus Disease-2019 (Covid-19) telah dilaporkan dapat menyebabkan gangguan penglihatan. Wu, Duan, et al (2020) melaporkan bahwa dari 38 pasien dewasa yang dilaporkan, 28 (73,7\%) pasien terkonfirmasi Covid-19 dan 2 $(5,2 \%)$ pasien diantaranya positif SARS-CoV-2 dalam konjungtiva serta nasofaring. Sebanyak 12 $(31,6 \%)$ pasien memiliki manifestasi ocular yang ditandai dengan konjungtivitis, termasuk hyperemia konjungtiva, kemosisosis, epifora atau peningkatan sekresi. Pasien anak juga dilaporkan telah mengalami gangguan penglihatan karena terinfeksi Covid-19. Wu, Liang, et al (2020) melaporkan dalam sebuah kasus anak berusia 2 tahun 10 bulan mengalami konjungtivitis dan dermatitis kelopak mata pada hari ketujuh ketika terkonfirmasi Covid-19. Gejala tersebut menghilang 5 hari kemudian dengan konfirmasi negatif Covid-19 pada 12 hari perawatan.

Laporan kasus dari Salducci \& La Torre (2020) melaporkan bahwa Covid-19 dapat terdeteksi dalam air mata dan sekresi konjungtiva pada pasien pneumonia Covid-19 dengan konjungtivitis. Laporan kasus ini menunjukkan konjungtivitis virus yang parah pada pasien yang didiagnosis dengan Covid-19 di kapal Diamond Princess ditandai dengan mata merah, iritasi dan bengkak dengan sekresi serosa transparan, kemosis konjungtiva, pseudomembran fibrin dan sel-sel inflamasi pada konjungtiva tarsal disertai dengan kelenjar getah bening preauricular dan submaxillaries yang membesar. Hong et al (2020) dalam penelitiannya melaporkan bahwa 
dari 56 kasus yang dilaporkan, 15 (27\%) pasien memiliki gejala mata yang memburuk, 6 (11\%) pasien mengalami mata prodromal sebelum timbulnya penyakit.

(Amesty et al., 2020) melaporkan bahwa sebuah tinjauan literature mengungkapkan bahwa hasil penelitian menunjukkan bahwa gejala ocular umumnya muncul pada pasien dengan pneumonia Covid-19 yang parah dan konjungtivitis bukan menifestasi umum dari penyakit tetapi kontak dengan mata pasien terinfeksi Covid-19 bisa menjadi salah satu rute penularan.

c. Manifestasi Cedera Otot Rangka (Sindrom Guillain-Barré)

Beberapa laporan kasus yang mengungkapkan bahwa Coronavirus disease-2019 (Covid-19) yang terkait dengan manifestasi cedera otot rangka seperti sindrom guillain barre. Amin et al (2020), H. Zhao (2020), Alberti et al (2020), Sedaghat \& Karimi (2020), Termini et al (2020), Virani et al (2020) Menyatakan bahwa terjadi keluhan mati rasa dan kelemahan otot ektremitas atas dan atau bawah selama terinfeksi Coronavirus Disease 2019 dengan pemeriksaan RT-PCR positif.

\section{KESIMPULAN}

Berdasarkan dari hasil review dan pembahasan yang telah dilakukan, dapat diambil kesimpulan seperti dibawah ini :

a. Coronaviruse disease-2019 dapat menginfeksi siapa saja baik laki-laki maupun perempuan, namun jenis kelamin laki-laki lebih rentan untuk terinfeksi.

b. Manifestasi klinis neurologis pada orang yang terinfeksi Coronaviruse disease-2019 dapat dibagi menjadi 3 bagian :

1. Sistem sarat pusat

Manifestasi sistem saraf pusat dapat berupa sakit kepala, myalgia, serebrovaskular akut, mual dan muntah, pusing, gangguan kesadaran, ataksia, dan kejang.

2. Sistem saraf tepi

Manifestasi sistem saraf tepi dapat berupa gangguan penciuman dan perasa, dan gangguan penglihatan.

3. Cedera otot rangka Manifestasi klinis cedera otot rangka dimanifestasikan dengan syndrome guillane barre.

\section{DAFTAR PUSTAKA}

Alberti, P., Beretta, S., Piatti, M., Karantzoulis, A., Piatti, M. L., Santoro, P., Viganò, M., Giovannelli, G., Pirro, F., 
Montisano, D. A., Appollonio, I., \& Ferrarese, C. (2020). Guillain-Barré syndrome related to COVID-19 infection. Neurology: Neuroimmunology and Neurolnflammation, 7(4), 1-3. https://doi.org/10.1212/NXI.000000000 0000741

Altin, F., Cingi, C., Uzun, T., \& Bal, C. (2020). Olfactory and gustatory abnormalities in COVID-19 cases. European Archives of Oto-Rhino-Laryngology, 0123456789. https://doi.org/10.1007/s00405-02006155-9

Amesty, M. A., Alió del Barrio, J. L., \& Alió, J. L. (2020). COVID-19 Disease and Ophthalmology: An Update. Ophthalmology and Therapy. https://doi.org/10.1007/s40123-02000260-y

Amin, M., Ayromlou, H., Jahanbakhsh, N., \& Hadavi, P. (2020). Since January 2020 Elsevier has created a COVID-19 resource centre with free information in English and Mandarin on the novel coronavirus COVID- 19 . The COVID-19 resource centre is hosted on Elsevier Connect, the company's public news and information . January.

Beltrán-Corbellini, Á., Chico-García, J. L., Martínez-Poles, J., Rodríguez-Jorge, F., Natera-Villalba, E., Gómez-Corral, J., Gómez-López, A., Monreal, E., ParraDíaz, P., Cortés-Cuevas, J. L., Galán, J. C.,
Fragola-Arnau, C., Porta-Etessam, J., Masjuan, J., \& Alonso-Cánovas, A. (2020). Acute-onset smell and taste disorders in the context of Covid-19: a pilot multicenter PCR-based casecontrol study. European Journal of Neurology, 1-4. https://doi.org/10.1111/ene.14273

Chary, E., Carsuzaa, F., Trijolet, J. P., Capitaine, A. L., Roncato-Saberan, M., Fouet, K., Cazenave-Roblot, F., Catroux, M., Allix-Beguec, C., \& Dufour, X. (2020). Prevalence and Recovery From Olfactory and Gustatory Dysfunctions in Covid-19 Infection: A Prospective Multicenter Study. American Journal of Rhinology and Allergy. https://doi.org/10.1177/194589242093 0954

Chen, T., Wu, D., Chen, H., Yan, W., Yang, D., Chen, G., Ma, K., Xu, D., Yu, H., Wang, H., Wang, T., Guo, W., Chen, J., Ding, C., Zhang, X., Huang, J., Han, M., Li, S., Luo, X., ... Ning, Q. (2020). Clinical characteristics of 113 deceased patients with coronavirus disease 2019: Retrospective study. The BMJ, 368(December 2019), 1-14. https://doi.org/10.1136/bmj.m1091

Giacomelli, A., Pezzati, L., Conti, F., Bernacchia, D., Siano, M., Oreni, L., Rusconi, S., Gervasoni, C., Ridolfo, A. L., Rizzardini, G., Antinori, S., \& Galli, M. 
(2020). Self-reported olfactory and taste disorders in SARS-CoV-2 patients: a cross-sectional study. Clinical Infectious Diseases: An Official Publication of the Infectious Diseases Society of America, Xx Xxxx, 2-3. https://doi.org/10.1093/cid/ciaa330

Guan, W., Ni, Z., Hu, Y., Liang, W., Ou, C., He, J., Liu, L., Shan, H., Lei, C., Hui, D. S. C., Du, B., Li, L., Zeng, G., Yuen, K. Y., Chen, R., Tang, C., Wang, T., Chen, P., Xiang, J., ... Zhong, N. (2020). Clinical characteristics of coronavirus disease 2019 in China. New England Journal of Medicine, 382(18), 1708-1720. https://doi.org/10.1056/NEJMoa20020 32

Hong, N., Yu, W., Xia, J., Shen, Y., Yap, M., \& Han, W. (2020). Evaluation of ocular symptoms and tropism of SARS-CoV-2 in patients confirmed with COVID-19. Acta Ophthalmologica, 1-7. https://doi.org/10.1111/aos.14445

Ikawaty, R. (2020). Dinamika Interaksi Reseptor ACE2 dan SARS-COV-2 Terhadap Manifestasi Klinis COVID-19. 1(2), 70-76.

Jiska Cohen-Mansfield, Maha Dakheel-Ali, MDb, Marcia S. Marx, PhDb, Khin Thein, MDb, and Natalie G. Regier, P. (2017). 乳鼠心肌提取 HHS Public Access. Physiology \& Behavior, 176(1), 139148. https://doi.org/10.1016/j.physbeh.2017 .03 .040

Kleina, S. L., Marriott, I., \& Fish, E. N. (2014). Sex-based differences in immune function and responses to vaccination. Transactions of the Royal Society of Tropical Medicine and Hygiene, 109(1), 9-15.

https://doi.org/10.1093/trstmh/tru167

Lechien, J. R., Chiesa-Estomba, C. M., De Siati, D. R., Horoi, M., Le Bon, S. D., Rodriguez, A., Dequanter, D., Blecic, S., El Afia, F., Distinguin, L., ChekkouryIdrissi, Y., Hans, S., Delgado, I. L., CalvoHenriquez, C., Lavigne, P., Falanga, C., Barillari, M. R., Cammaroto, G., Khalife, M., ... Saussez, S. (2020). Olfactory and gustatory dysfunctions as a clinical presentation of mild-to-moderate forms of the coronavirus disease (COVID-19): a multicenter European study. European Archives of Oto-RhinoLaryngology, 277(8), 2251-2261. https://doi.org/10.1007/s00405-02005965-1

Li, Q., Guan, X., Wu, P., Wang, X., Zhou, L., Tong, Y., Ren, R., Leung, K. S. M., Lau, E. H. Y., Wong, J. Y., Xing, X., Xiang, N., Wu, Y., Li, C., Chen, Q., Li, D., Liu, T., Zhao, J., Liu, M., ... Feng, Z. (2020). Early transmission dynamics in Wuhan, China, of novel coronavirus-infected pneumonia. New England Journal of 
Medicine, 382(13), 1199-1207. https://doi.org/10.1056/NEJMoa20013 16

Mao, L., Jin, H., Wang, M., Hu, Y., Chen, S., He, Q., Chang, J., Hong, C., Zhou, Y., Wang, D., Miao, X., Li, Y., \& Hu, B. (2020). Neurologic Manifestations of Hospitalized Patients with Coronavirus Disease 2019 in Wuhan, China. JAMA Neurology.

https://doi.org/10.1001/jamaneurol.20 20.1127

Mehraeen, E., Behnezhad, F., Salehi, M. A., Noori, T., Harandi, H., \& SeyedAlinaghi, S. A. (2020). Olfactory and gustatory dysfunctions due to the coronavirus disease (COVID-19): a review of current evidence. European Archives of OtoRhino-Laryngology, 0123456789. https://doi.org/10.1007/s00405-02006120-6

Montalvan, V., De Toledo, J., \& Nugent, K. (2020). Mechanisms of stroke in coronavirus disease 2019. Journal of Stroke, 22(2), 282-283. https://doi.org/10.5853/jos.2020.01802

Netland, J., Meyerholz, D. K., Moore, S., Cassell, M., \& Perlman, S. (2008). Severe Acute Respiratory Syndrome Coronavirus Infection Causes Neuronal Death in the Absence of Encephalitis in Mice Transgenic for Human ACE2. Journal of Virology, 82(15), 7264-7275. https://doi.org/10.1128/jvi.00737-08

Qiu, C., Cui, C., Hautefort, C., Haehner, A., Zhao, J., Yao, Q., Zeng, H., Nisenbaum, E. J., Liu, L., Zhao, Y., Zhang, D., Levine, C. G., Cejas, I., Dai, Q., Zeng, M., Herman, P., Jourdaine, C., de With, K., Draf, J., ... Lu, H. (2020). Olfactory and Gustatory Dysfunction as an Early Identifier of COVID-19 in Adults and Children: An International Multicenter Study. Otolaryngology-Head and Neck Surgery, 2019, 019459982093437. https://doi.org/10.1177/019459982093 4376

Salducci, M., \& La Torre, G. (2020). COVID-19 emergency in the cruise's ship: a case report of conjunctivitis. La Clinica Terapeutica, 171(3), e189-e191. https://doi.org/10.7417/CT.2020.2212

Sedaghat, Z., \& Karimi, N. (2020). Since January 2020 Elsevier has created a COVID-19 resource centre with free information in English and Mandarin on the novel coronavirus COVID-19. The COVID-19 resource centre is hosted on Elsevier Connect, the company's public news and information . January.

Sonja A. Rasmussen, MD, MS, J. C. S. (2020). Since January 2020 Elsevier has created a COVID-19 resource centre with free information in English and Mandarin on the novel coronavirus COVID-. Ann Oncol, January, 19-21. 
https://doi.org/10.1007/s00134-020-

05991-x.Bizzarro

Spinato, Giacomo, Fabbris, C., Polesel, J., Cazzador, Diego, Borsetto, Daniele, Hopkins, Claire, Boscolo-Rizzo, \& Paolo. (2020). Alterations in Smell or Taste in Mildly Symptomatic Outpatients With SARS-CoV-2 Infection. Alterations in Smell or Taste in Mildly Symptomatic Outpatients With SARS-CoV-2 Infection, 1-2.

https://doi.org/10.1093/cid/ciaa330

Termini, E., Description, F. P., Street, D., Id, B. S., Schedule, E., Code, F. F., Funds, F., Code, S. F., Funds, S., Funds, L., Funds, T., Lindsay, D. S., Nosek, B. A., Key, I., Order, N., County, C., District, A., County, M., Works, P., ... Components, A. P. (2020). No 主観的健康感を中心 とした在宅高齢者における 健康関連 指標に関する共分散構造分析Title. 21(1), 1-9.

Virani, A., Rabold, E., Hanson, T., Haag, A., Elrufay, R., Cheema, T., Balaan, M., \& Bhanot, N. (2020). Guillain-Barré Syndrome associated with SARS-CoV-2 infection. IDCases, 20, e00771. https://doi.org/10.1016/j.idcr.2020.e00 771

vom Steeg, L. G., \& Klein, S. L. (2016). SeXX Matters in Infectious Disease Pathogenesis. PLoS Pathogens, 12(2), 16. https://doi.org/10.1371/journal.ppat.10 05374

Wang, D., Yin, Y., Hu, C., Liu, X., Zhang, X., Zhou, S., Jian, M., Xu, H., Prowle, J., Hu, B., Li, Y., \& Peng, Z. (2020). Clinical course and outcome of 107 patients infected with the novel coronavirus, SARS-CoV-2, discharged from two hospitals in Wuhan, China. Critical Care, 24(1), 1-9. https://doi.org/10.1186/s13054-02002895-6

Wang, Z., Qiang, W., \& Ke, H. (2020). A Handbook of 2019-nCoV Pneumonia Control and Prevention. Hubei Science and Technology Press, 1-108.

Wu, P., Duan, F., Luo, C., Liu, Q., Qu, X., Liang, L., \& Wu, K. (2020). Characteristics of Ocular Findings of Patients with Coronavirus Disease 2019 (COVID-19) in Hubei Province, China. JAMA Ophthalmology, 2019, 4-7. https://doi.org/10.1001/jamaophthalm ol.2020.1291

Wu, P., Liang, L., Chen, C. B., \& Nie, S. Q. (2020). A child confirmed COVID-19 with only symptoms of conjunctivitis and eyelid dermatitis. Graefe's Archive for Clinical and Experimental Ophthalmology, 258(7), 1565-1566. https://doi.org/10.1007/s00417-02004708-6 
Yan, C. H., Faraji, F., Prajapati, D. P., Ostrander, B. T., \& DeConde, A. S. (2020). Self-reported olfactory loss associates with outpatient clinical course in COVID-19. International Forum of Allergy and Rhinology, 10(7), 821-831.

https://doi.org/10.1002/alr.22592

Zhao, H. (2020). Since January 2020 Elsevier has created a COVID-19 resource centre with free information in English and Mandarin on the novel coronavirus COVID- 19 . The COVID-19 resource centre is hosted on Elsevier Connect, the company' $s$ public news and information. Guillain-Barré Syndrome Associated with SARS-CoV-2 Infection: Causality or Coincidence?, January, 3.
Zhao, S., Cao, P., Chong, M. K. C., Gao, D., Lou, Y., Ran, J., Wang, K., Wang, W., Yang, L., He, D., \& Wang, M. H. (2020). COVID-19 and gender-specific difference: Analysis of public surveillance data in Hong Kong and Shenzhen, China, from January 10 to February 15, 2020. Infection Control and Hospital Epidemiology, 41(6), 750-751. https://doi.org/10.1017/ice.2020.64

Zhao, Y., Zhao, Z., Wang, Y., Zhou, Y., Ma, Y., \& Zuo, W. (2020). Single-cell RNA expression profiling of ACE2, the putative receptor of Wuhan 2019-nCov. BioRxiv, 2020.01.26.919985. https://doi.org/10.1101/2020.01.26.91 9985 